\title{
The Microstructure and Wear Resistance of the Ti-assisted Hot Plasma Nitrided Layer
}

\author{
Fei HUANG ${ }^{1,2}$, Zhen'an REN ${ }^{2}$, Wanli LU $^{3}$, Wumu LIU ${ }^{2}$ * \\ ${ }^{1}$ Northeast Electric Power University, Engineering Training Teaching Center, No. 169 Changchun Road, Jilin, 132012, \\ China \\ ${ }^{2}$ Jilin University, School of Materials Science and Engineering, No. 5988 Renmin Street, Changchun, 130022, China \\ ${ }^{3}$ Tenneco FAWSN(Changchun) Automobile Parts Co.,Ltd., Changchun 130013,China \\ crossref http://dx.doi.org/10.5755/j01.ms.25.2.19142
}

Received 27 September 2017; accepted 30 March 2018

\begin{abstract}
In order to improve the wear resistance of the surface nitrided layer of 1060 aluminum matrix, the nitrogen containing thermal plasma Ti-assisted nitriding method was adopted to obtain the strengthening phases of AlN and TiN simultaneously. The influence of the nitriding technological parameter on Ti-assisted nitriding was studied through changing the nitrogen containing thermal plasma current $(\mathrm{I}=100$ to $160 \mathrm{~A})$ and the flow ratio of the nitriding atmosphere ( $\mathrm{Ar} / \mathrm{N}_{2}=8 / 2,6 / 4,4 / 6$ and 2/8 L/min). The nitrided layer prepared under the Ti-assisted nitriding conditions was composed of $\mathrm{AlN}$ and $\mathrm{Al}$ solid solution, $\mathrm{Al}_{3} \mathrm{Ti}$ and TiN phases. The average microhardness of TiN dense distribution area was $1025 \mathrm{HV}_{0.1}$, significantly higher than that of AlN dense distribution area $\left(589 \mathrm{HV}_{0.1}\right)$. When the proportion of nitrogen in the plasma gas was $40 \%$ and the current was $120 \mathrm{~A}$, the weight loss of the nitrided layer after wear was $3.4 \mathrm{mg}$, and its average friction coefficient was 0.214 . Compared with those of aluminum matrix, the friction coefficient of the surface nitrided layer reduced by $33 \%$, and the wear resistance capacity increased by 4.5 times. Ti-assisted nitriding could obtain the AlN and TiN compound strengthening effect, so as to improve the wear resistance of the nitrided layer significantly. Key words: nitriding, microstructure, AlN/TiN, microhardness, wear resistance.
\end{abstract}

\section{INTRODUCTION}

As a kind of lightweight engineering material, aluminum and aluminum alloy have received extensive attention in the fields of aviation and automobile industry. With the advantages of light weight, corrosion resistance, low cost, easy processing and reutilization, they have been widely used in the industrial fields. However, aluminum and aluminum alloy also have some disadvantages, like low hardness and poor wear resistance $[1,2]$. In order to enhance the wear-resistant capability of aluminum and aluminum alloy, solid solution strengthening and thermal treatment strengthening can be adopted to improve the overall mechanical performance of the materials [3]. In addition, it is more environmental friendly and high efficient to modify the surface of aluminum and aluminum alloy matrix to obtain the hard surface deposition layer or form the compound layer and thus improve the wear resistance $[4,5]$. In all kinds of surface strengthening layers of aluminum and aluminum alloy, the nitride coatings (such as AlN and TiN) have attracted much attention [6,7]. There are many methods to prepare the nitride layer, such as plasma immersion ion implantation deposition (PIIID) [8, 9], plasma enhanced chemical vapor deposition (PECVD) [10-12], thermal plasma arc discharge surface nitriding (TPADSN) [13], plasma sprayed (PSP) [14, 15] and other technologies. The surface wearability of aluminum and aluminum alloy matrix after nitriding treatment will be greatly improved.

\footnotetext{
* Corresponding author. Tel.: +86-18243086065.

E-mail address: liuwm15@mails.jlu.edu.cn (W. Liu)
}

As it is known, coating can be prepared by the abovementioned methods in general cases, but the growth rate of coating prepared by PECVD and PIIID is relatively low, so it is difficult to form a thick coating. In addition, the adhesive force of deposited coatings to the substrate is relatively poor. Therefore, the surface nitridation methods, including laser nitriding [16] and plasma nitriding [17 - 19], are the best methods for surface modification of aluminum alloys. Among various sorts of plasma nitriding treatments, hot plasma nitriding is superior to other nitriding processes in the possibility of the partially nitriding of components and the efficiency of nitriding process. In previous studies, unalloyed steel [20] and titanium [17] have been successfully nitridized.

However, only a few papers published so far are known for describing the formation of nitrided layers on aluminium substrates by this technique. Thus, further experiments must be done to prove that this technique can be accepted for industrial applications. In this work, since both $\mathrm{Al}$ and $\mathrm{Ti}$ are metal elements which can be easily nitrided [21-25], the Ti-assisted nitriding treatment can be carried out through pre-covering Ti powders when using the nitrogen containing plasma for the surface nitriding of aluminum matrix, so as to obtain the surface nitrided layer with better wear resistance. 


\section{EXPERIMENTAL MATERIALS, METHODS AND EQUIPMENTS}

\subsection{Experimental materials}

The industrial pure aluminum 1060 measuring $70 \mathrm{~mm} \times 25 \mathrm{~mm} \times 8 \mathrm{~mm}$ (length $\times$ width $\times$ height $)$ was used the matrix material. Its composition is shown in Table 1. The average particle size of the atomized Ti powders is $100 \mu \mathrm{m}$.

Table 1. The chemical composition of 1060 substrate (wt \%)

\begin{tabular}{|c|c|c|c|l|l|l|}
\hline $\mathrm{Si}$ & $\mathrm{Mg}$ & $\mathrm{Fe}$ & $\mathrm{Mn}$ & $\mathrm{Ti}$ & $\mathrm{Cu}$ & $\mathrm{Al}$ \\
\hline 0.28 & 0.17 & 0.35 & 0.07 & 0.03 & 0.006 & $\mathrm{Bal}$. \\
\hline
\end{tabular}

The aluminium surface was pre-treated before the experiment by grinding with the corundum sandpaper (\#600), washing with ethanol for 10 minutes with an ultrasonic cleaner and drying. Pre-coated titanium powders and water glass were mixed in a certain proportion to ensure the moldability and the proper viscosity. Then the mixture was applied to the surface of the pre-treated test plate evenly. After that, the pre-coated test plate was placed in a cool and ventilated place to dry for 24 hours, and then be dried in a drying furnace at $100{ }^{\circ} \mathrm{C}$ for $1 \mathrm{~h}$.

\subsection{Experimental methods and equipments}

The principle of the nitrogen containing hot plasma Tiassisted nitriding experiment is shown in Fig. 1. WP-300 type argon arc welding machine was used. The diameter of tungsten electrode was $3 \mathrm{~mm}$. The distance between tungsten electrode and the surface of the aluminum matrix was about $3 \mathrm{~mm}$. The welding gun was fixed on a trolley whose walking speed can be controlled. The mixed gas with different proportions of high purity nitrogen and argon was injected into the welding gun and then flowed from the nozzle. Argon was used as a shielding gas. It also formed the stably burning arc with nitrogen, namely, nitrogen containing hot plasma. The nitrogen containing hot plasma arc was ignited to heat the surface of aluminium matrix to form a molten pool locally. Then, the walking trolley was started to make nitrogen ions, atoms and molecules in hot plasma combine with aluminium melt and high-temperature titanium to form $\mathrm{AlN}$ and $\mathrm{TiN}$ and then the nitrided layer on the surface of aluminium matrix.

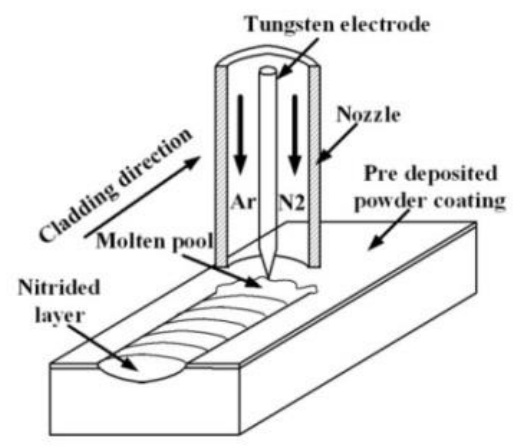

Fig. 1. The principle diagram of the pre-coated titanium nitriding

After the nitrogen containing hot plasma Ti-assisted nitriding experiment on aluminum matrix, the nitrided layer was cut into the metallographic specimens measuring
$20 \mathrm{~mm} \times 12 \mathrm{~mm} \times 8 \mathrm{~mm}$ (length $\times$ width $\times$ height $)$ along the cross section. The cross section of the metallographic specimens was grinded, polished and then put into the $\mathrm{NaOH}$ aqueous solution with the volume fraction of $20 \%$ for chemical corrosion. After that, the specimens were cleaned with alcohol and dried by an air blower. ZEISS Axio Scope A1-type optical microscope was used to observe and photograph different tissue areas within the nitrided layer. EVO18 SEM equipped with EDS of Link ISIS was employed to observe and analyze the microstructure and phase composition of metallographic specimens. To determine the phase composition of the nitrided layer, D/Max 2500 PC X-ray diffractometer of Rigaku Corporation was used for the phase analysis $(\lambda \mathrm{CuK} \alpha=0.15418 \mathrm{~nm}$, scan rate is $4 \% \mathrm{~min})$. Everone MH-3-type micro-hardness tester was used to measure the micro-hardness of typical phases in the nitrided layer. Since the tissues were tiny, the method of testing the microhardness of the areas with dense phase distribution was applied. 5 dense areas were selected for each phase, and the average hardness was taken as characterization. The test load was $0.98 \mathrm{~N}$, and the dwell time was $15 \mathrm{~s}$. The friction and wear test of the nitrided layer was carried out at room temperature by using a MG-2000 type pin-on-disc Tribometer. The nitrided layer on the surface of aluminum matrix was prepared into the pin-shaped wear samples measuring $6 \mathrm{~mm} \times 6 \mathrm{~mm} \times 8 \mathrm{~mm}$ (length $\times$ width $\times$ height) by the way of dry sliding friction and wear. Hard alloy ring (YG8) was taken as the counterpart. Its outer diameter was $80 \mathrm{~mm}$, its inner diameter was $50 \mathrm{~mm}$, and its width was $16.5 \mathrm{~mm}$. The wear load was set to be $20 \mathrm{~N}$. The shaft was controlled to rotate at $100 \mathrm{rpm}$. It rotated by a total of 2000 circles. The friction torque value was recorded every 50 rotations. The coefficient of friction was then calculated. Each sample had a total of 40 friction coefficients. The friction coefficients in the process of friction and wear were mapped to calculate the average friction coefficient of each worn specimen and test the weight loss after wear to characterize the wear resistance.

\section{EXPERIMENTAL RESULTS AND ANALYSIS}

Two groups of the Ti-assisted nitrogen containing hot plasma nitriding experiments were carried out on aluminum matrix. One group used various currents $(\mathrm{I}=100$ to $160 \mathrm{~A})$ under the arc with a mixture atmosphere of $20 \%$ argon and $80 \%$ nitrogen. The other one used different proportions of nitrogen in gas flow rate $\left(\mathrm{Ar} / \mathrm{N}_{2}=8 / 2,6 / 4,4 / 6,2 / 8 \mathrm{~L} / \mathrm{min}\right)$ at a fixed arc current of $120 \mathrm{~A}$. The walking speed of the arc was $3.8 \mathrm{~mm} / \mathrm{s}$ in the two groups of experiments. The influence of the change in process parameters on the microstructure and properties of the nitrided layer was tested.

\subsection{Typical microstructure and phase composition of the Ti powder-assisted nitrided layer}

Fig. 2 shows the typical microstructure of the surface nitrided layer obtained under the conditions of $\mathrm{I}=160 \mathrm{~A}$ and $\mathrm{Ar} / \mathrm{N}_{2}=8 / 2$. Fig. 2 shows the shape and appearance of the nitrided layer. The nitrided region has tissue regions with different colors, which means it is composed of some yellow dendritic phases and blue stripes and massive phases. 


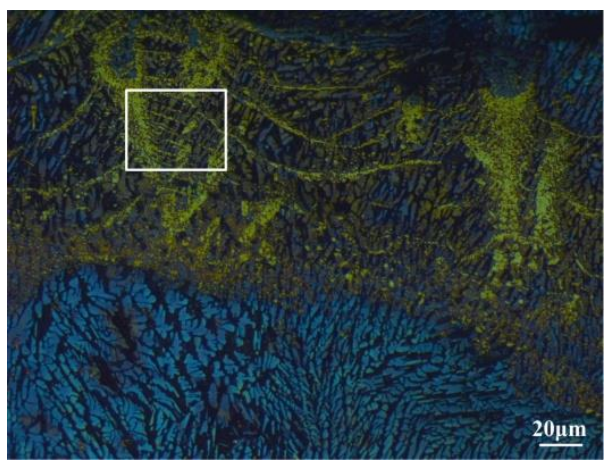

Fig. 2. Typical microstructures of nitride layer formed on the precoated substrate with $\mathrm{Ti}$

Fig. 3 shows the XRD analysis results of the nitrided layer at different currents and different atmospheres. The Ti powder-assisted nitrided surface layer was composed of four phases, namely, $\mathrm{AlN}, \mathrm{Al}$ solid solution, $\mathrm{Al}_{3} \mathrm{Ti}$ and $\mathrm{TiN}$.

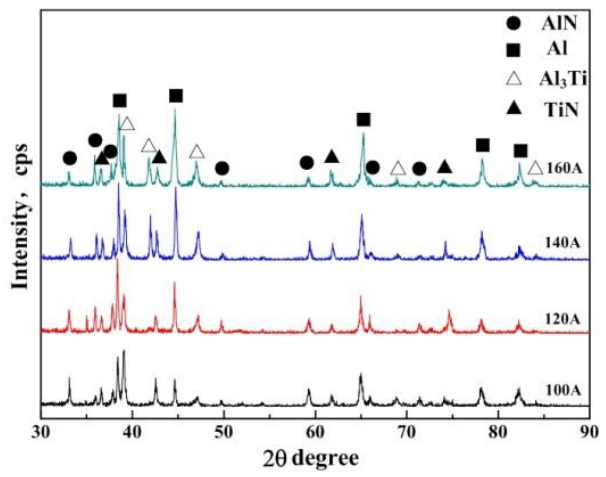

a

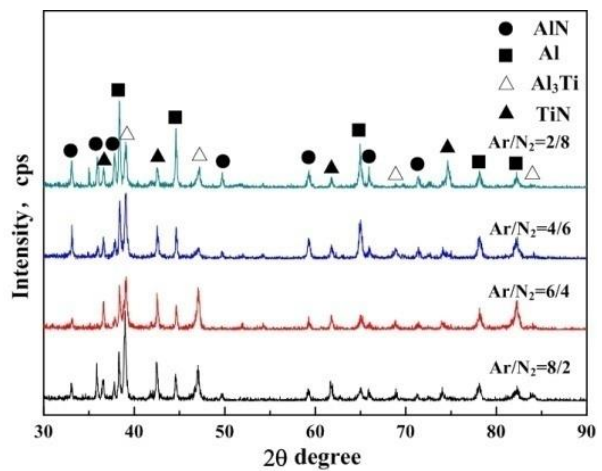

b

Fig. 3. The XRD analysis results of the nitrided layer: $a$-different currents; $b$-different atmospheres

SEM observation was carried out on the densely distribution area of blue tissue phases at the lower part of the nitrided layer under the light microscope, as shown in Fig. 4. EDS composition analysis was made on Point A and $\mathrm{B}$ in Fig. $4 \mathrm{~b}$ to get the analysis results shown in Table 2. Thus, A was composed of $\mathrm{N}, \mathrm{Al}$ elements, and a small amount of Ti. The small tissues between the blue acicular structures could be determined as AlN phases based on the XRD analysis results. AlN particles were surrounded by aluminium solid solution. This was because nitrogen solid soluble in aluminium melt reacted with aluminium melt directly to precipitate $\mathrm{AlN}$. The ratio of $\mathrm{Al}$ atoms to Ti atoms in the blue acicular structure of $B$ was close to $3: 1$. Based on the XRD analysis, $\mathrm{B}$ could be determined to be $\mathrm{Al}_{3} \mathrm{Ti}$ phase.
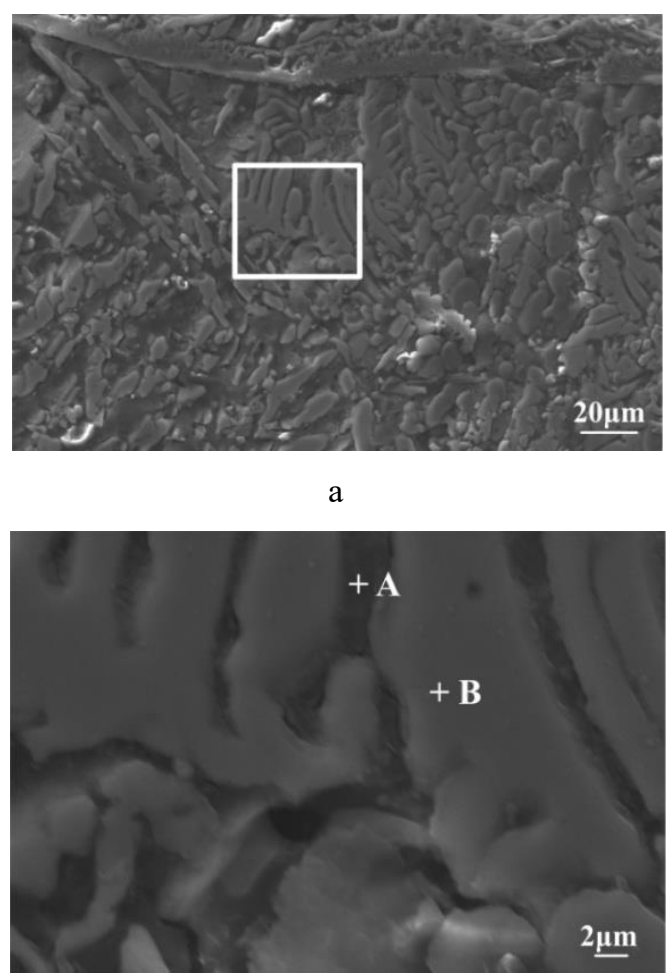

b

Fig. 4. The SEM photos and EDS spot analyses of the typical microstructures at lower of the nitrided layer: a - The region of blue striped microstructure; $b$-local magnification of Fig. 4 a and location of EDS analysis point

Table 2. The EDS component analysis results of points A and B

\begin{tabular}{|c|c|c|c|c|}
\hline \multirow{2}{*}{ Element } & \multicolumn{2}{|c|}{ Spot A } & \multicolumn{2}{c|}{ Spot B } \\
\cline { 2 - 5 } & wt.\% & at.\% & wt.\% & at.\% \\
\hline $\mathrm{N}$ & 14.91 & 25.68 & - & - \\
\hline $\mathrm{Al}$ & 84.57 & 74.04 & 62.53 & 74.76 \\
\hline $\mathrm{Ti}$ & 0.53 & 0.28 & 37.47 & 25.24 \\
\hline Total & \multicolumn{2}{|c|}{100} & \multicolumn{2}{c|}{100} \\
\hline
\end{tabular}

Fig. 5 provided SEM of the nitrided layer corresponding to the marked areas shown in Fig. 2. Its interior was composed of massive tissues with certain orientation, particle phases inside the massive tissues and horizontally distributed strip tissue phases. EDS composition analysis was carried out on $\mathrm{C}, \mathrm{D}$ and $\mathrm{E}$ in Fig. $5 \mathrm{~b}$ to get the analysis results in Table 3.

The EDS analysis of $\mathrm{C}$ showed that the ratio of $\mathrm{N}$ atoms to $\mathrm{Ti}$ atoms was close to $1: 1$. It could be confirmed based on the XRD analysis results that the horizontally strip tissues were $\mathrm{AlN}$ phases, the massive tissues were $\mathrm{Al}_{3} \mathrm{Ti}$ phases, the particle phases inside the massive tissues were TiN phases, and they were dispersed within $\mathrm{Al}_{3} \mathrm{Ti}$ phases.

Table 3. The EDS component analysis results of points C, D and E

\begin{tabular}{|c|c|c|c|c|c|c|}
\hline \multirow{2}{*}{ Element } & \multicolumn{2}{|c|}{ Spot C } & \multicolumn{2}{c|}{ Spot D } & \multicolumn{2}{c|}{ Spot E } \\
\cline { 2 - 7 } & wt.\% & at.\% & wt.\% & at.\% & wt.\% & at.\% \\
\hline $\mathrm{N}$ & 23.76 & 52.75 & - & - & 36.23 & 51.21 \\
\hline $\mathrm{Al}$ & - & - & 61.58 & 74.00 & 63.77 & 48.79 \\
\hline $\mathrm{Ti}$ & 76.23 & 47.25 & 38.42 & 26.00 & - & - \\
\hline Total & \multicolumn{2}{|c|}{100} & \multicolumn{2}{c|}{100} & \multicolumn{2}{c|}{100} \\
\hline
\end{tabular}




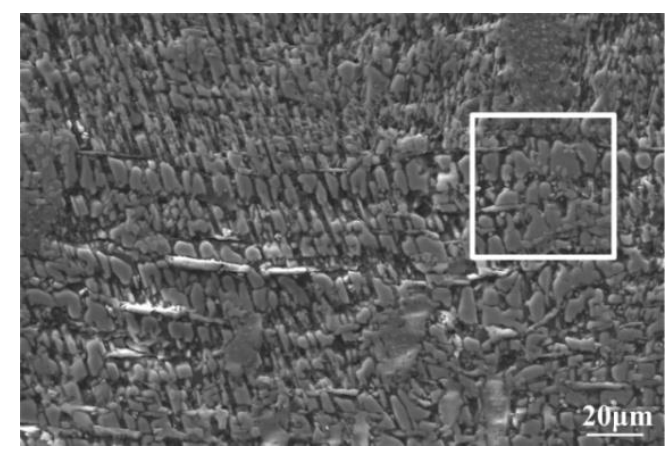

a

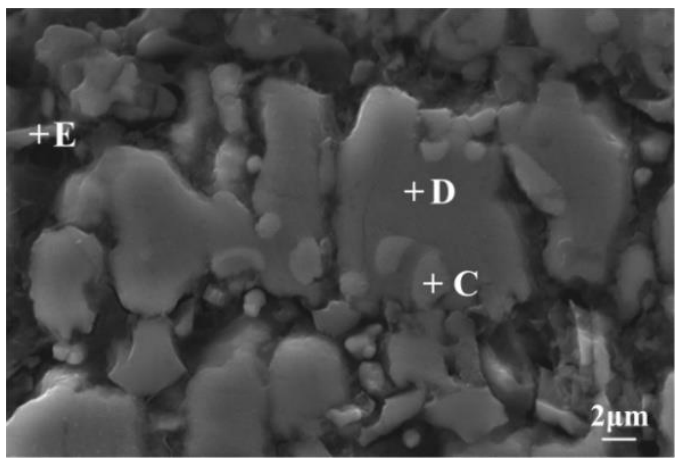

b

Fig. 5. The SEM image and EDS spot analyses of the typical microstructure of the upper layer of the nitride layer: $a$-local magnification of Fig. 2; b-local magnification of Fig. 5 a and location of EDS analysis point

\subsection{The microhardness and wear resistance of the nitrided layer}

From the typical structure test of the Ti powder-assisted nitrided layer it was found that the average microhardness was $77 \mathrm{HV}_{0.1}$ for $\mathrm{Al}$ solid solution, $589 \mathrm{HV}_{0.1}$ for the dense distribution area of $\mathrm{AlN}, 692 \mathrm{HV}_{0.1}$ for the dense distribution area of $\mathrm{Al}_{3} \mathrm{Ti}$, and $1025 \mathrm{HV}_{0.1}$ for the dense distribution area of yellow TiN. The last was obviously higher than the maximum hardness of the surface nitrided layer of aluminum matrix without $\mathrm{Ti}$ powders in the literature $\left(690 \mathrm{HV}_{0.1}\right)$ [18], the nitride layer in this paper contains $\mathrm{Al}_{3} \mathrm{Ti}$ and $\mathrm{TiN}$ phases, which have a higher microhardness, therefore, the microhardness of the nitride layer is increased.

In order to compare with 1060 pure aluminum matrix, the wear loss of pure aluminium was tested to be $15.6 \mathrm{mg}$, and the average friction coefficient was 0.3189 under the same friction and wear test conditions.

Fig. 6 presents the influence curve of the hot plasma current on the weight loss of the surface nitrided layer after wear and the friction coefficient when the nitrogen containing hot plasma atmosphere was $\mathrm{Ar} / \mathrm{N}_{2}=8: 2$. In the nitriding process, with the increase of the current, the volume of molten pool expanded. Then, the pre-coated titanium powder could react better with aluminium melt and form $\mathrm{Al}_{3} \mathrm{Ti}$ intermetallic compound. Aluminum, titanium and nitrogen from hot plasma were synthesized at high temperature to form $\mathrm{AlN}$ and $\mathrm{TiN}$, which increased the average hardness of the nitrided layer. When the current increased to $160 \mathrm{~A}$, due to the large amount of heat input, aluminium melt reached the most, while the amount of precoated titanium powder was constant, resulting in the more aluminium solid solution within the nitride layer, and the reduction of the average hardness of the nitrided layer. With the increase of the current from $100 \mathrm{~A}$ to $160 \mathrm{~A}$, the hardness value of the nitride layer increased first and then decreased, the weight loss of the nitrided layer after wear reduced with the increasing current till $140 \mathrm{~A}$, where the weight loss reached the minimum value of $5.1 \mathrm{mg}$, hence began to increase, as shown in Fig. 6 a. Its wear resistance was as 3 times as that of the pure aluminium matrix. According to the friction coefficient variation law in Fig. 6 b, with the increase of the current, the friction coefficient decreased first and then increased. Then, the average friction coefficient of each specimen could be calculated, as shown in Table 4. Thus, when the arc current was $140 \mathrm{~A}$, the average friction coefficient of the nitrided layer was the minimum, being 0.2005 , far lower than that of pure aluminum matrix.

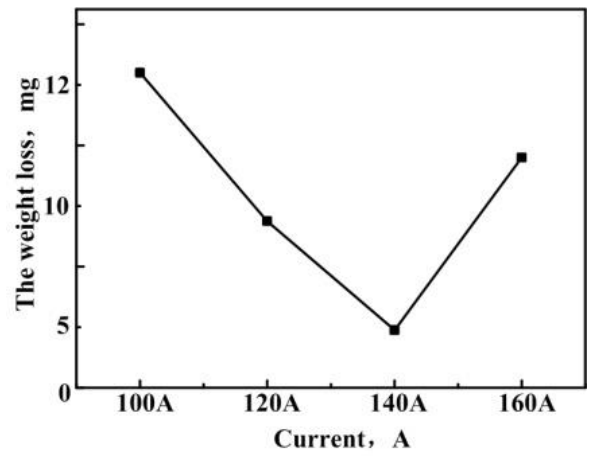

a

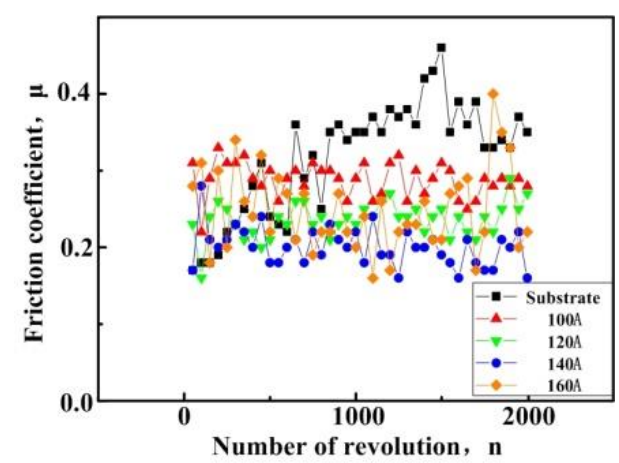

$\mathrm{b}$

Fig. 6. Effect of current on wear loss and friction coefficient of the nitride layer formed on the pre-coated substrate with Ti: $a$-weight loss; $b$ - friction coefficient

Table 4. The average friction coefficients of the nitride layer formed on the pre-coated substrate with Ti powders at different current

\begin{tabular}{|c|c|c|c|c|}
\hline Electric current, A & 100 & 120 & 140 & 160 \\
\hline $\begin{array}{c}\text { The average friction } \\
\text { coefficient, } \mu\end{array}$ & 0.2880 & 0.2360 & 0.2005 & 0.2483 \\
\hline
\end{tabular}

Fig. 7 presents the influence curve of the proportion of nitrogen in the hot plasma atmosphere on the weight loss of the Ti powder-assisted nitrided layer after wear and the friction coefficient when the current was $120 \mathrm{~A}$. The average friction coefficient of the nitrided layer at different atmospheres is calculated and is shown in Table 5 . 


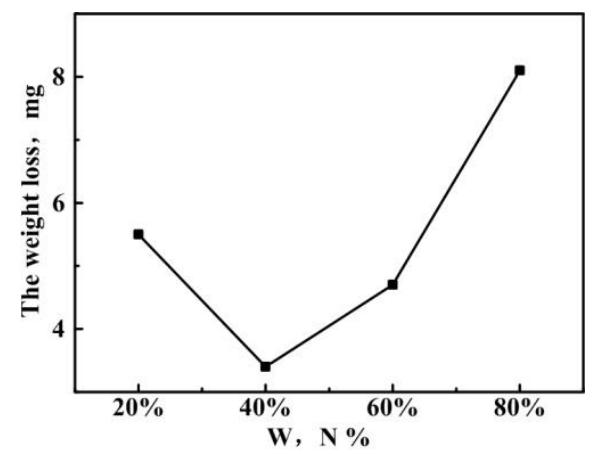

a

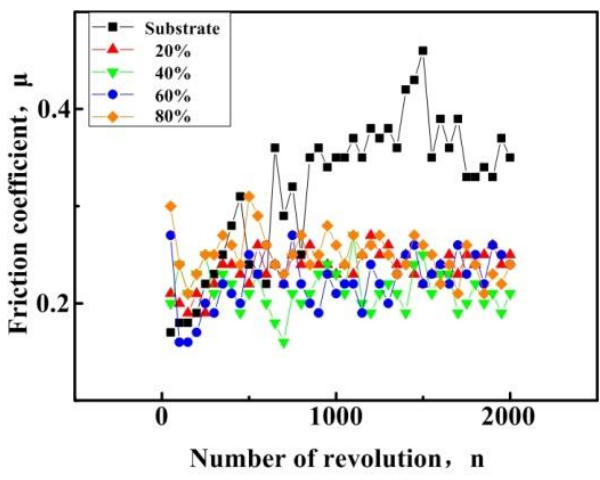

b

Fig. 7. Influence of the atmospheres on wear loss and friction coefficient of the nitride layer formed on the pre-coated substrate with Ti: $a$-weight loss; $b$-friction coefficient

Table 5. The average friction coefficients of the nitride layer formed on the pre-coated substrate with Ti powders at different atmospheres

\begin{tabular}{|c|c|c|c|c|}
\hline $\begin{array}{c}\text { Arc atmosphere, } \\
\text { Ar/ } \mathrm{N}_{2}\end{array}$ & $8: 2$ & $6: 4$ & $4: 6$ & $2: 8$ \\
\hline $\begin{array}{c}\text { The average friction } \\
\text { coefficient, } \mu\end{array}$ & 0.2360 & 0.2140 & 0.2238 & 0.2498 \\
\hline
\end{tabular}

According to Fig. 7 and Table 5, when the proportion of nitrogen was $40 \%$ and the current was $120 \mathrm{~A}$, the weight loss of the nitrided layer after wear was only $3.4 \mathrm{mg}$, and the average friction coefficient was only 0.214 . The friction coefficient of the nitrided layer reduced by $33 \%$ compared with that of pure aluminum, but its wear resistance capacity increased by 4.5 times.

In the wear test, the abrasion loss and the average friction coefficient of the substrate were obviously higher than those of the nitride layer, which meant that the nitriding treatment of AlN and TiN could significantly improve the performance of the aluminium substrate. The results also showed that as the concentration of nitrogen in the $\mathrm{Ar} / \mathrm{N}_{2}$ mixture increased, the weight loss of the nitride layer decreased, which was probably a result of an increase in the AlN, TiN phase concentration as the $\mathrm{Ar} / \mathrm{N}_{2}$ ratio increased. However, as the ratio of nitrogen in the arc atmosphere exceeded $40 \%$, the mass of hot plasma of nitrogen in the plasma arc increased faster, and the increase of the ratio of nitrogen in the arc also caused the temperature of plasma to rise, thus further expanding the welding pool of aluminium substrate, so nitrides in the nitrided layer increased with the increase of the ratio of nitrogen; however, due to the high ionization potential of nitrogen, the energy after nitrogen ionization was relatively high, the substrate obtains relatively high energy fusion, the pool was further expanded, resulting in that the nitridation of aluminium melt in the nitrided layer is not sufficient, and the content of nitrides was relatively reduced. The increase of solid solution of aluminium in the nitrided layer is shown in Fig. $3 \mathrm{~b}$. The hardness was reduced and the weightlessness of wear of the nitrided layer increased. It is in good agreement with the results of [18] nitrogen-containing thermal plasma aluminium nitride matrix. When the proportion of nitrogen exceeded $40 \%$, the amount of $\mathrm{Al}$ solid solution in the nitride layer increased, the weight loss and average friction coefficient of the nitride layer gradually increased, and wear resistance decreased.

\section{CONCLUSIONS}

In this paper, the microstructure and wear resistance of the nitride layer were analyzed through reinforcing the aluminium matrix by nitrogen-containing hot plasma titanium-assisted nitriding. The following conclusions were obtained:

1. When using the nitrogen containing plasma for the $\mathrm{Ti}$ powder-assisted surface nitriding of aluminum matrix, the surface layer was composed of four phases, namely, AlN, $\mathrm{Al}$ solid solution, $\mathrm{Al}_{3} \mathrm{Ti}$ and $\mathrm{TiN} . \mathrm{Al}_{3} \mathrm{Ti}$ intermetallic compounds in the AlN and TiN enrichment areas in the nitrided layer were in the dendrite shape.

2. The average hardness value was $77 \mathrm{HV}_{0.1}$ for $\mathrm{Al}$ solid solution, $589 \mathrm{HV}_{0.1}$ for the dense distribution area of AlN, $692 \mathrm{HV}_{0.1}$ for the dense distribution area of $\mathrm{Al}_{3} \mathrm{Ti}$, and $1025 \mathrm{HV}_{0.1}$ for the dense distribution area of TiN. When making the nitrogen containing hot plasma surface treatment on pure aluminum, pre-coating $\mathrm{Ti}$ powders in the molten pool had the function of nitriding assistance.

3. When the nitrogen containing hot plasma atmosphere was $\mathrm{Ar} / \mathrm{N}_{2}=8: 2$, with the increase of the plasma current, the weight loss of the nitrided layer reduced first and then increased. The weight loss was the minimum and the wear resistance capacity was 3 times higher than that of pure aluminum matrix when the current was $140 \mathrm{~A}$. When the proportion of nitrogen was $40 \%$, and the current was $120 \mathrm{~A}$, the weight loss of the nitrided layer was $3.4 \mathrm{mg}$, and the average friction coefficient was 0.214. Compared with those of pure aluminum matrix, the friction coefficient of the nitrided layer reduced by $33 \%$, and its wear resistance capacity increased by 4.5 times. Ti assisted nitriding could receive AlN and TiN compound strengthening effect, so as to significantly improve the wear resistance of the nitrided layer.

\section{Acknowledgments}

The work is supported by the Northeast Electric Power University Doctor Scientific Research Starting Foundation, China. (BSJXM-2018231)

\section{REFERENCES}

1. Miller W.S., Zhuang, L., Bottema, J., Wittebrood, A., 
De Smet, P., Haszler, A., Vieregge, A. Recent Development in Aluminium Alloys for the Automotive Industry Materials Science and Engineering: A 280 (1) 2000: pp. 37-49. https://doi.org/10.1016/S09215093(99)00653-X

2. Nayak, S., Dahotre, N.B. Surface Engineering of Aluminum Alloys for Automotive Engine Applications JOM 56 (1) 2004: pp. $46-48$.

http:// doi.org/10.1007\%2fs11837-004-0272-6

3. Su, X.C. Strengthening of Aluminum Alloys Light alloy Fabrication Technology 24 (9) 1996: pp. 2-5. (in Chinese).

4. Jagielski, J., Piatkowska, A., Aubert, P., LegrandBuscema, C., Le Paven, C., Gawlik, G., Piekoszewski, J., Werner, Z. Effects of High Ddose Nitrogen Implantation into Aluminum Vacuum 70 (2) 2003: pp. 147-152. http://doi.org/10.1016/S0042-207X(02)00633-4

5. Czerwiec, T., Renevier, N., Michel, H. Low-Temperature Plasma-Assisted Nitriding Surface and Coatings Technology 131 (1) 2000: pp. 267-277. http://doi.org/10.1016/S0257-8972(00)00792-1

6. Huashun, Y., Kim, J.D., Kang, S.B. The Formation of AlN and TiN Particles During Nitrogen Bearing Gas Injection into Al-Mg-Ti Melt Materials Science and Engineering: A 386 (1) 2004: pp. $318-325$.

http://doi.org/10.1016/j.msea.2004.07.049

7. Ye, H.Z., Liu, X.Y., Luan, B. In Situ Synthesis of AlN in $\mathrm{Mg}-\mathrm{Al}$ Alloys by Liquid Nitridation Journal of materials processing technology 166 (1) 2005: pp. 79-85. http://doi.org/10.1016/j.jmatprotec.2004.06.033

8. Manova, D., Mändl, S., Rauschenbach, B. Evolution of Surface Morphology During Ion Nitriding of Aluminium Surface and Coatings Technology 180 2004: pp. $118-121$.

http://doi.org/10.1016/j.surfcoat.2003.10.148

9. Manova, D., Huber, P., Sienz, S., Gerlach, J.W., Mändl, S., Rauschenbach, B. Dependence of Ion Beam Induced Nitrogen Diffusion in Aluminum on Oxygen Impurities Journal of Vacuum Science \& Technology A: Vacuum, Surfaces, and Films 20 (1) 2002: pp. 206-213. http://doi.org/10.1116/1.1427887

10. Tailleur, A., Achour, A., Djouadi, M.A., Le Brizoual, L., Gautron, E., Tristant, P. PECVD Low Temperature Synthesis of Carbon Nanotubes Coated with Aluminum Nitride Surface and Coatings Technology 211 2012: pp. $18-23$.

http://doi.org/10.1016/j.surfcoat.2011.09.048

11. Minea, T.M., Point, S., Gohier, A., Granier, A., Godon, C., Alvarez, F. Single Chamber PVD/PECVD Process for in Situ Control of the Catalyst Activity on Carbon Nanotubes Growth Surface and Coatings Technology 200 (1) 2005: pp. 1101-1105.

http://doi.org/10.1016/j.surfcoat.2005.01.053

12. Bouchkour, Z., Tristant, P., Thune, E., DublancheTixier, C., Jaoul, C., Guinebretière, R. Aluminum Nitride Nano-Dots Prepared by Plasma Enhanced Chemical Vapor Deposition on Si (111) Surface and Coatings Technology 205 2011: pp. S586-S591. http://doi.org/10.1016/j.surfcoat.2011.01.011

13. Renevier, N., Czerwiec, T., Billard, A., Von Stebut, J., Michel, H. A Way to Decrease the Nitriding Temperature of Aluminium: the Low-Pressure Arc-Assisted Nitriding Process Surface and Coatings Technology 116 1999: pp. 380-385.

https://doi.org/10.1016/S0257-8972(99)00209-1
14. Li, J.F., Liao, H., Normand, B., Cordier, C., Maurin, G., Foct, J., Coddet, C. Uniform Design Method for Optimization of Process Parameters of Plasma Sprayed TiN Coatings Surface and Coatings Technology $176(1)$ 2003: pp. $1-13$. http://doi.org/10.1016/S0257-8972(03)00019-7

15. Zou, D., Yan, D., Xiao, L., Dong, Y. Characterization of Nanostructured TiN Coatings Fabricated by Reactive Plasma Spraying Surface and Coatings Technology 202 (10) 2008: pp. $1928-1934$. http://doi.org/10.1016/j.surfcoat.2007.08.022

16. Meneau, C., Andreazza, P., Andreazza-Vignolle, C., Goudeau, P., Villain, J.P., Boulmer-Leborgne, C. Laser Surface Modification: Structural and Tribological Studies of AlN Coatings Surface and Coatings Technology 100 1998: pp. $12-16$. http://doi.org/10.1016/S0257-8972(97)00580-X

17. Li, X., Ren, Z.A., Sun, D.Q. An Investigation of Nitrided Layer Prepared by Direct Current Nitrogen Arc Discharge Materials Science and Engineering: A 443 (1) 2007: pp. $219-223$. http://doi.org/10.1016/j.msea.2006.08.031

18. Zheng, X., Ren, Z., Li, X., Wang, Y. Microstructural Characterization and Mechanical Properties of Nitrided Layers on Aluminum Substrate Prepared by Nitrogen Arc Applied Surface Science 259 2012: pp. 508-514. http://doi.org/10.1016/j.apsusc.2012.07.075

19. Ebisawa, T., Saikudo, R. Formation of Aluminum Nitride on Aluminum Surfaces by ECR Nitrogen Plasmas Surface and Coatings Technology 86 1996: pp. 622-627. http://doi.org/10.1016/S0257-8972(96)02967-2

20. Hassel, T., Birr, C., Bach, F.W. Surface Zone Modification by Atmospheric Plasma-Nitriding (APN) with the aid of the Transmitted Plasma-arc Key Engineering Materials 438 2010: pp. $147-154$

https://doi.org/10.4028/www.scientific.net/KEM.438.147

21. Spencer, P.J. Computational Thermochemistry: from Its Early Calphad Days to a Cost-Effective Role in Materials Development and Processing Calphad 25 (2) 2001: pp. $163-174$. http://doi.org/10.1016/S0364-5916(01)00040-2

22. Michalski, A. Crystallization of Composite Coatings of AlNTiN, TiN-AlN-Ti and TiN-Ti 3 Al-Ti from the Reactive Pulse Plasma by the Use of a Hot Two-Sectional Electrode Journal of Materials Science Letters 4 (3) 1985: pp. $251-254$. http://doi.org/10.1007/BF00719782

23. Li, X., Sun, D.Q., Zheng, X.Y., Ren, Z.A. Effect of $\mathrm{N}_{2} / \mathrm{Ar}$ Gas Flow Ratios on the Nitrided Layers by Direct Current Arc Discharge Materials Letters $62(2)$ 2008: pp. $226-229$. http://doi.org/10.1016/j.matlet.2007.04.109

24. López-Callejas, R., Millán-Flores, H., MuñozCastro, A.E., Valencia-Alvarado, R., MercadoCabrera, A., Eguiluz, R.P., $\quad$ Barocio, S.R., de la Piedad Beneitez, A. Nitriding of 6061t6 Aluminium by Plasma Immersion Ion Implantation at Low Energy Progress in Organic Coatings 67 (3) 2010: pp. 361-364. http://doi.org/10.1016/j.porgcoat.2009.10.021

25. Meletis, E.I., Yan, S. Formation of Aluminum Nitride by Intensified Plasma Ion Nitriding Journal of Vacuum Science \& Technology A Vacuum Surfaces \& Films 9(4) 1991: pp. 2279-2284. http://doi.org/10.1116/1.577309 